\title{
From Automatic Data Processing to Digitalization: What is Past is Prologue
}

\author{
Leif Sundberg ${ }^{(\otimes)}(\mathbb{D}$ \\ Mid Sweden University, Holmgatan 10, 85170 Sundsvall, Sweden \\ leif.sundberg@miun.se
}

\begin{abstract}
Governments across the world are intensifying their use of digital technology. One way to generate an understanding of the effects of technology in the public sector is to study values. The purpose of this paper is to investigate how values in the Swedish national e-Government have developed over time. This research studies Swedish government documents between 1961 and 2018 during three periods of computerization: Automatic Data Processing, Information Technology, and Digitalization. A theoretical framework that consists of four value positions (i.e. professionalism, efficiency, service, and engagement) is utilized. The findings suggest that technological paradigms tend to generate value congruence in policy documents, followed by value divergence in evaluations. Currently, digitalization is perceived as the enabler of several values. While both IT and digitalization are referred to as tools or means, the development towards an information, knowledge, or data-driven society is also described as inevitable. The service ideal became dominant through the use of internet-based technology, while efficiency is often prioritized in large-scale projects. Engagement values are associated with a futuristic form of democracy in government documents, but rarely converted into practice. The role of professionalism is two-fold: it acts both as an enabler and as a constraint to the other values. The paper concludes with suggesting that the current development of adapting laws and regulations to enable digitalization might lead to an eroded bureaucracy, with uncertain value.
\end{abstract}

Keywords: e-Government $\cdot$ Digitalization $\cdot$ Values

\section{Introduction}

According to Heeks and Bailur [17], the term 'electronic government' was first mentioned in 1993; the abbreviation 'e-Government' gained prominence in 1997. This research field gained popularity at the end of the 1990s and has since steadily grown due to governments intensifying their use of digital technology. Another common term to describe practice and research in this area is 'digital government.' The digital aspect of digital government can be understood 
as either the process of digitization (i.e. converting analog signals to digital) or digitalization, which refers to the macro-level changes associated with increased usage of digital technology [3]. In the public sector, digitalization can be linked to the idea of transformative government - a reformed sector that utilizes digital technology to enable certain values. Bannister and Connolly [2] argued that the ideals associated with transformative government can be expressed as public values, or modes of behavior that are considered "right." Bannister and Connolly [1] contended that governments, professionals, and scholars tend to focus on the latest technological developments before the older technologies have been fully exploited or understood. Fukumoto and Bozeman [15] argued that longitudinal and historical studies can improve theory and research on public values. Grönlund contended that eGovernment research must become "deeper", through an increased understanding of the relation between technology, organization and government values [16]. Stouby-Persson et al. [26] performed a study of how values developed over time in Denmark's e-Government strategies from 1994 and 2016. These authors called for additional studies on the stability of values in e-Government strategies over time in other national contexts.

Against this backdrop, the purpose of this paper is to investigate how values in Sweden's national e-Government have developed over time. The research is carried out through a content analysis of historical Swedish government documents.

The history of Swedish computing post World War II has been subject to a large number of publications in prior research (see e.g. [20,22,24]). This paper adds to this research by contributing with a public values perspective, and by adding material from the digitalization era.

The paper proceeds as follows. Section 2 provides a theoretical framework of e-Government values. Section 3 discusses materials and methods utilized in this study. The results are presented in Sect. 4, followed by a discussion in Sect. 5 . Finally, conclusions are drawn in Sect. 6.

\section{Theoretical Framework: e-Government Value Positions}

Different paradigms in the public sector have replaced and advanced the roles of citizens, policymakers, and the government administration. Rose et al. [37], (see also [36]) presented a value classification based on these paradigms. This section continues with a more detailed outline of the respective positions, which are summarized in Table 1.

\subsection{Professionalism}

In traditional Weberian governments, rules, due process, and neutrality are the core values that should determine how the public sector acts. The bureaucracy is independent, robust, and consistent, governed by rule of law, where the public record is the basis of accountability. The role of e-Government, according to the professionalism ideal, is to provide a flexible and secure digital public record 
Table 1. e-Government value positions

\begin{tabular}{l|l}
\hline Position & Representative values \\
\hline Professionalism & Durability, equity, legality and accountability \\
\hline Efficiency & Value for money, productivity, and performance \\
\hline Service & Public service, citizen centricity, service level and quality \\
\hline Engagement & Democracy, deliberation, and participation \\
\hline
\end{tabular}

to support standardized administrative procedures; IT constitutes an information infrastructure that enacts the regulatory system. The public manager is a rational-legal authority limited by its sphere of competence within a hierarchical organization that builds on fixed areas of activities and division of labor [37] The bureaucratic organization is superior to other forms of organization: Weber compared the bureaucratic apparatus superiority with a machine's superior production ability over non-mechanical modes of production. Weber's view on the future of the bureaucracy was rather dystopic: he argued that we are destined to live in an 'iron cage' of rationalization where the individual has very little control [40].

\subsection{Efficiency}

In the 1980s, a new paradigm that is closely connected to the market economy emerged: new public management (NPM). According to NPM, Weberian bureaucracy failed to answer customer needs, which led to under-performance and poor legitimacy. The dominating core value of NPM is efficiency: The public administration is slim and efficient, minimizing waste of public resources. The citizen is seen as a customer whose demands can be satisfied by proper government supply. In NPM, the distinction between the public and private sectors is removed and accountability is achieved through obtaining results, which are measured in monetary terms. Furthermore, the ideal organizational structures are small competing units, inspired by private sector corporations [18]. IT is associated with automation, and is considered a tool for productivity that substitutes labor. The role of e-Government is to streamline, rationalize and transform the public administration around digital technologies [37].

\subsection{Service}

The main criticism of NPM is its emphasis on efficiency by copying features from the private sector. Moore [25] argued that, in the private sector, the individual can refrain from consuming a product whose value is perceived as limited, while in the public sector, the government uses its coercive power of taxation to produce services that may be mandatory for individuals. The challenge for the public manager is to identify what consequences will produce public value. IT is seen as a service enabler in relation to this ideal, increasing access and 
quality of services. Dunleavy et al. [9] used the term "digital-era governance" to describe this paradigm shift and identified three characteristic themes: reintegration (as opposed to fragmentation), needs-based holism (i.e. reorganization to create seamless, non-stop solutions) and digitization processes (e.g. electronic service delivery).

\subsection{Engagement}

The engagement ideal builds on the idea of actively engaging citizens through participatory processes. Based on liberal democratic ideas, civil society stakeholders are expected to act as co-creators in, for example, policy development. The role of IT and e-Government in this ideal is to support deliberative and communicative interaction between governments and citizens [37]. In this new paradigm, sometimes termed New Public Service, governance is based on democratic citizenship, community, and civil society. The primary role of the public servant in the engagement paradigm is to help citizens articulate and meet their shared interests rather than attempt to control or steer society [6].

\subsection{Value Relationships}

The value positions have some features in common, while others are fundamentally different. The end products of both Weberian bureaucracy and New public management is efficiency, while respective position's approach to ethics differ: Weber's bureaucracy is rule-based, while NPM is performance based: rule ethics versus consequence ethics. In one paradigm, the citizen is a client, in the other a customer. Value positions can be congruent or divergent; they can support or conflict with each other. Congruent value relations can be causal (i.e. one value will inevitably give rise to another value), a prerequisite (i.e. one value requires another value), a side effect (i.e. one value might cause another value), or synergistic (two or more values are entangled in a mutually dependent achievement). Divergent value relations can be competing (e.g. over resources), negating (i.e. one value may end another value), or transformative (i.e. one value will turn into another value) [37].

\section{Materials and Methods}

The unit of analysis in this paper was Swedish policy documents. The research took the following research steps:

1. Formulate and motivate purpose (Sect. 1).

2. Select and motivate sources of data (further elaborated on below).

3. Choose categories for coding the data (Sect.2).

4. Interpret the material through content analysis. 
The criterion used for inclusion is that the documents should reflect perceptions on values associated with digital technology (e.g. "Information Technology") in the public sector. The included documents are of three kinds: (a) results of comprehensive investigations on the use, or potential use, of digital technology (b) strategies from central government, and (c) evaluation reports from appointed agencies. The total number of documents studied is 22 , which are referred to in the results section. The material is by no means a complete set of documents on Swedish computing history, but rather a sample of documents that reflects perceptions of values over time.

Since there is already an existing theory (see Sect. 2) about the phenomenon, directed content analysis was utilized [19], using an interpretative stance. In this type of analysis, existing theory is used to generate coding schemes for the included variables. The four value positions in Sect. 2 were used to create the coding categories and operational definitions. Content expressing values was highlighted and placed into one of the four categories (i.e. professionalism, efficiency, service, and engagement), together with an interpretation of their relation (i.e. congruence or divergence).

\section{Results}

This study identified three periods of computerization in the Swedish public sector following World War II: Automatic Data Processing (ADP), IT, and Digitalization. This section proceeds with the results from the content analysis presented in chronological order in 4.1-4.3.

\subsection{Automatic Data Processing}

In 1955, a committee was directed by the Department of Finance to investigate the potential use of electronic computational machines within public administration, particularly cost savings. The committee released two reports, describing how a computer worked (basically, the von Neumann architecture), together with potential areas of application (often in the form of keeping registries) and predictions about their future use. Although some concerns about questionable effects of computers in the United States are raised, the fast development of new and improved, transistor-based computers suggests a bright future: The fast technical development is accompanied by an increased interest for the new machines. With increased knowledge, ADP is increasingly becoming a step towards increased rationalization. ADP is described as a part of a structural transformation of society, which is characterized by increased automation. One section describes "online" use by establishing a remote connection to a computer. Although the current term 'interoperability' is not used in the report, ideas about how to interlink registers between systems started to take hold. To achieve this goal, additional investigations and standardization were deemed necessary $[12,13]$. One of the reports report concluded with a suggestion to create a new government entity to coordinate ADP. However, no new government entity was created. 
Instead, the coordinating role was given to the The Swedish Agency for Public Management (APM), which, at the time, was responsible for rationalization matters.

The optimism of the 1960s was replaced in the 1970s by economic recession and worries about the potential harmful effects of computer technology. This decade was characterized by increased political control of technology. A 1972 report, points out that, Through the coordination of several information systems, an increased amount of information can be processed. Due to this, ADP creates increased risks for privacy intrusions. The responsible committee emphasizes both the concerns raised in the public debate and the benefits of using computers for rationalization purposes in the report [23]. The discussion and the political debate led to the Swedish Data Protection Law in 1973, one of the first of its kind in the world. This law essentially required government agencies to apply for a permit to create a register and allowed individuals to request a copy of the information about them found in the registers. The law was later replaced by the Data Protection Act in 1998, and the General Data Protection Regulation in 2018.

A 1976 report on the topic of ADP coordination includes a paragraph about the potential use of computers in political processes, stating: One of the most spectacular forms of direct democratic participation that has been suggested is elections and voting processes aided by computer technology and telecommunications. It is also recognized that ADP can upset the balance of power, not only within the public administration but also among individuals: Government agencies and individuals with access to ADP have significant advantages compared to those who do not. The committee also acknowledges the difficulties in assessing the effects of ADP in monetary terms since the impacts in the form of service improvements are often qualitative in nature. One recognized problem in the report is that the Swedish word for efficiency and effectiveness is the same (effektivitet), while the two terms have different meanings in English. The report concludes that cost savings should be the valid interpretation of the term [4]. A 1979 proposition from the central government emphasizes efficiency, but also recognize additional purposes with ADP, such as service improvements [27]. Computer technology changed during this time, shifting from large central computers to decentralized, networked desktop computers suitable for office use. In 1984, the National Audit Office (NAO) conducted an evaluation of investments in "small-scale ADP". They conclude that cost savings had not been achieved due to investments in technology not being accompanied by necessary organizational changes: initiatives are developed by enthusiasts rather than being based on benefit realization. However, the report also mentions improvements in quality and service [35]. During the 1980s, the APM released guides on how to develop and evaluate ADP investments in monetary terms. The APM had less influence on the computerization in the 1980s though, when decentralized evaluations became an important part of the long-term governance model (mentioned in [38]). Political control over computers was reduced during the 1980s, as computer investments should be decided on by each agency separately, in line with new management ideals. 


\subsection{Information Technology}

In 1988, ADP and IT were considered synonyms by a minister, describing how the number of computerized work spaces in the public sector had tripled between 1983 and 1987 [28]. In 1994, a speech by the Swedish prime minister marked the starting point for when IT became the established term for computerized technology. Sweden should become a leading IT-nation no later than 2010. For the public sector, this goal meant adapting Internet-based technology to become a "24-hour government", a term that was used in parallel with a direct translation of "e-Government" [39]. Policies formulated by experts in collaboration with ministers express optimism regarding the potential values that can be achieved by IT, not only in the public sector, but in the whole society. Documents describe how the new technology, a convergence of several media such as computers, text, sound, television and radio technology, could give "wings to man's ability" in the "epoch shift" towards an "information-" or "knowledge society". Although IT is sometimes referred to as a tool or a means in these documents, the outcome in the form of a new society is described as inevitable [21,29]. The goal for the public sector in this society is to increase efficiency, service, and quality. Legality continued to serve as a constraint to these goals: $A$ range of legal obstacles prevent a rational use of IT. Moreover, current regulations do not offer enough protection to avoid misuse, and unwanted consequences of the new technology [29]. An IT strategy from 2000 states, Without a doubt, IT has improved the conditions for increased efficiency and quality...However, holistic indicators to follow up on these goals are missing...The websites of several agencies are offering good service at low cost [30].

A series of investigations discuss the potential for the Internet to increase access to democratic spaces. A final report from the "democracy investigation" in 2001 summarizes the then-current initiatives as mostly part of a "service democracy," whereby information from politicians is supplied to civil society and not used as a tool for active engagement. Concerns are also raised about unequal access to and usage of technology depending on age, sex and income [5]. Subsequent government reports contain reservations concerning these digital divides since many policies build on the assumption that citizen demand, and use, government services.

After the millennium shift, which was characterized by a declining IT industry during the dotcom crisis, the effects of computerized technology in the public sector were questioned. In 2004, the NAO concludes that ...the [24-hour government] reform has had limited impact...Severe flaws prevent the implementation of electronic government, which have affected citizens, businesses and the government agencies [34]. Due to a significant focus on cost savings, few advanced services targeted at smaller user groups were created. The use of email among government entities is described as a threat to the rule of law, and the work to remove legal obstacles to implement e-services is reported as slow. The report also criticized the lack of governance from the central government and parliament. A group of general directors known as the "e-Delegation" was formed in 2009 to enable coordination of e-Government issues. The e-Delegation was also 
tasked with exploring the possible development of e-democracy but eventually refrained from carrying out this investigation [10].

\subsection{Digitalization}

Like ADP and IT, digitalization and IT have existed in parallel. The European Union released a digital agenda for Europe in 2010. A Swedish digital agenda was released by the first expert group with the word 'digitalization' in its name in 2011: The Digitalization Council. They were replaced by a Digitalization commission in 2012. In the subsequent years, the service ideal received additional attention. A 2012 strategy titled "With the Citizen in the Center" contained three sub-goals for the Swedish e-Government: 1. An easier life for the citizen (through increased use of digital services), 2. An administration that supports innovation and participation (by enabling open data), and 3. increased quality and efficiency (through standardization, security and, increased digitalization) [31].

The title IT Minister was changed to Digitalization Minister in 2016. The material on digitalization contains several parallels to the IT movement in the 1990s: the goal to become a leading nation in technology and an increased optimism of what could be achieved with the new technology. The reports produced by the expert groups often describes digitalization as a highly transformative force, similar to how ADP was perceived in the 1960s and IT in the 1990s. A report from the Digitalization commission contends that digitalization is: [T]he most transformative process since industrialization... Digitalization may enable the development of a democratic and sustainable welfare society that we can barely conceive today. The report states that the public administration can achieve higher efficiency and create better welfare services through the use of digital technology. A rule-based bureaucracy is contrasted to individualization and flexibility, which are key-characteristics of the digital, data-driven society. Big data and machine learning are considered as potential remedies for the failure of earlier management ideals, however, privacy issues need to be subject to a "broad debate". In a scenario for the year 2030, digital technology is being used to enhance participation processes, as well as for digital voting [7]. A 2017 digitalization strategy states that the development of society is run and shaped by digitalization. While digitalization is not a means in itself, people need to be able to adapt to the change, which requires innovation and leadership. The public sector should strive to become an innovative and collaborative public administration that is under the rule of law and is efficient, with well-developed quality, service, and accessibility, and that contributes to the work of the European Union [32]. Further reports suggest that digital services should be the prioritized channel for governments ('digital first'). These reports include suggestions for regulations meant to improve the formalized governance of digitalization [14], legal investigations with the purpose of improving security when outsourcing, and allowing automatic decision-making by artificial intelligence [8].

In a series of evaluation reports, the National Financial Management Authority (NFMA) concludes that, many agencies are unaware of their IT costs, and 
generic tools for assessment are missing. NFMA also reveals that in large-scale projects internal efficiency tend to be the main goal, although citizen centricity is achieved by many agencies through user involvement in service design [11]. Similar findings are presented in a report on digital investments, where an expert group concludes that in large-scale projects, government agencies tend to prioritize efficiency [33].

\section{Discussion}

This section discusses the development of the value positions (i.e. professionalism, efficiency, service, and engagement) over time in the studied documents.

\subsection{Professionalism}

The computers in the public administration, which were installed in the 1960s, carried public records in large registers and constituted an infrastructure of which the main purpose was rationalization. It was soon realized that it was difficult to position and organize the use of computers within the bureaucratic system. The ability to connect computers to each other and coordinate the content of several registers had the potential to disrupt the structures of the public sector. Weberian bureaucracy favors hierarchical structures based on specialization and governed by the rule of law. Computerized technology, however, enables cross-organizational information flows through networks and integrated systems, which initially occurred through coordinating registries, later through networked desktop computers, and today, via Internet-based technology. The professionalism ideal has played two roles to this day: as both a constraint that negates other value positions and as a prerequisite that enables a secure and robust, yet flexible, public record. In the latest digitalization strategies, the work with adapting legal and organizational structures has intensified.

\subsection{Efficiency}

Throughout the entire period studied in this research, even before the establishment of the NPM ideals, efficiency plays a salient role in the computerization of the public sector. The purpose of investing in ADP was clear: to reduce the cost of the growing public sector. However, a recurring topic over time is how to assess these investments. In the 1970s, difficulties in assessing the effects of ADP implementations and concerns about cost overruns started taking hold. Moreover, the Swedish term effektivitet caused confusion since it can refer to both efficiency and effectiveness. The ideals of NPM during the IT and digitalization eras manifest themselves in continuous discussions about performance assessment, but also in the form of influence from private experts on the content of government policies. While the service ideal became dominant through the use of internet-based technology, reports suggest that efficiency remains prioritized in large-scale initiatives. 


\subsection{Service}

Service improvements were initially regarded as competing interpretations, or at best, side effects of efficiency. When the ability to deliver services via Internetbased technology was established in the 2000s, service would eventually become a prominent value position in e-Government strategies. Through the notion of "digital first," all government entities should primarily choose the channel of digital technology. However, the increased use of digital technology also comes with a negative side-effect: digital divides. Thus, the service ideal builds on the idea that digitalization is developed based on citizen demands, but struggles with the fact that not everyone can (or want to) use digital services.

\subsection{Engagement}

Engagement values are expressed in conjunction with the rapid changes in structures that increased use of digital technology brings. The first trace of engagement in the material is found in the end of the 1970s, where a report describes the use of computers for engaging citizens as a futuristic form of democracy. During the IT era in the 1990s, possibilities for facilitating engagement processes over the Internet are mentioned in government reports. These investigations end with a report in 2001, which states that no major progress has occurred in the area. Engagement ideals return in documents on digitalization: as a potential outcome of the use of open government data, and in a future scenario for the year 2030 where increased engagement processes and digital voting have been implemented.

\section{Conclusions}

This paper aimed to investigate how values in Sweden's national e-Government have developed over time. The research was conducted via a content analysis of Swedish government documents on computerization produced between 1961 and 2018. Four value positions from prior research were utilized to analyze the material: professionalism, efficiency, service, and engagement. Drawing on a historical account of the Swedish context as a case study, the results of this research contribute to a growing body of research on value traditions associated with the implementation of technology in the public sector.

The name for computerized technology has shifted over time, from Automatic Data Processing to IT, and digitalization. These eras are initiated with value congruence in policies describing a future society enabled by technology. Previously, these expectations have led to disappointments due to fundamental challenges that remains unresolved, including assessment problems and digital divides. Currently, digitalization is perceived as an enabler of several values. While both IT and digitalization are referred to as tools or means, the development towards a new information- knowledge-, or data-driven society is also described as inevitable. 
The service ideal became dominant through the use of internet-based technology, while efficiency is often prioritized in large-scale initiatives. Engagement values are associated with a futuristic form of democracy in government documents, but rarely converted into practice. Professionalism constrains the other values by acting as a barrier that prevents integration and interoperability, but also by enabling a secure public record that takes privacy issues into account. However, professionalism is also at stake, when laws and regulations are adapted to enable digitalization: when Weber's iron cage is replaced by a more fragile, digital construction, the current development might lead to an eroded bureaucracy, with uncertain value.

\section{References}

1. Bannister, F., Connolly, R.: Forward to the past: lessons for the future of e-government from the story so far. Inf. Polity 17(3), 211-226 (2012)

2. Bannister, F., Connolly, R.: ICT, public values and transformative government: a framework and programme for research. Gov. Inf. Q. 31(1), 119-128 (2014)

3. Brennen, S., Kreiss, D.: Digitization or digitalization. Culture Digitally (2014)

4. Datasamordningskommittén: SOU 1976:58: ADB och samordning. Finansdepartementet (1976)

5. Demokratiutredningen: SOU 2000:1: En uthållig demokrati! Politik för folkstyret på 2000-talet. Kulturdepartementet (2000)

6. Denhardt, R.B., Denhardt, J.V.: The new public service: serving rather than steering. Public Adm. Rev. 60(6), 549-559 (2000)

7. Digitaliseringskommissionen: SOU 2016:89: För digitalisering i tiden. Näringsdepartementet (2016)

8. Digitaliseringsrättsutredningen: SOU 2018:25: Juridik som stöd för den förvaltningens digitalisering. Regeringskansliet (2018)

9. Dunleavy, P., Margetts, H., Bastow, S., Tinkler, J.: New public management is dead-long live digital-era governance. J. Public Adm. Res. Theor. 16(3), 467-494 (2006)

10. E-delegationen: SOU 2015:66: En förvaltning som håller ihop. Näringsdepartementet (2015)

11. Ekonomistyrningsverket: Digitaliseringen av det offentliga Sverige - en uppföljning (2018)

12. Finansdepartementet: SOU1961:60: Den automatiska databehandlingens teknik (1961)

13. Finansdepartementet: SOU 1962:32: Automatisk databehandling (1962)

14. Finansdepartementet: SOU 2017:114: reboot - omstart för den digitala förvaltningen (2017)

15. Futumoto, E., Bozeman, B.: Public values theory: what is missing? Am. Rev. Public Adm. 1-14 (2018)

16. Grönlund, A.: Ten years of e-government: the 'end of history' and new beginning. In: Wimmer, M.A., Chappelet, J.-L., Janssen, M., Scholl, H.J. (eds.) EGOV 2010. LNCS, vol. 6228, pp. 13-24. Springer, Heidelberg (2010). https://doi.org/10.1007/ 978-3-642-14799-9_2

17. Heeks, R., Bailur, S.: Analyzing e-government research: perspectives, philosophies, theories, methods, and practice. Gov. Inf. Q. 24(2), 243-265 (2007) 
18. Hood, C.: A public management for all seasons? Public Adm. 69, 3-19 (1991)

19. Hsieh, H.F., Shannon, S.E.: Three approaches to qualitative content analysis. Qual. Health Res. 15(9), 1277-1288 (2005)

20. Ilshammar, L., Bjurström, A., Grönlund, Å.: Public e-services in sweden - old wine in new bottles? Scand. J. Inf. Syst. 17(2), 11-40 (2005)

21. IT-kommissionen: SOU 1994:118: Informationsteknologin: Vingar åt människans förmåga. Statsrådsberedningen (1994)

22. Johansson, M.: Smart, Fast and Beautiful : On Rhetoric of Technology and Computing Discourse in Sweden 1955-1995. No. 164 in Linköping Studies in Arts and Science (1997)

23. Justitiedepartementet: SOU 1972:47: Data och integritet (1972)

24. Lundin, P.: Computers in Swedish Society - Documenting Early Use and Trends. Springer, London (2012). https://doi.org/10.1007/978-1-4471-2933-2

25. Moore, M.H.: Creating Public Value - Strategic Management in Government. Harvard University Press, Cambridge (1995)

26. Persson, J.S., Reinwald, A., Skorve, E., Nielsen, P.A.: Value positions in e-government strategies: Something is (not) changing in the state of denmark. In: ECIS (2017)

27. Regeringen: Proposition 1978/79:121, om användningen av automatisk databehandling (ADB) i statsförvaltningen (1979)

28. Regeringen: Proposition 1987/88:95, om datapolitik för statsförvaltningen (1988)

29. Regeringen: Åtgärder för att bredda och utveckla användningen av informationsteknik (1996)

30. Regeringskansliet: Regeringens proposition 1999/2000:86 Ett informationssamhälle för alla. Näringsdepartementet (2000)

31. Regeringskansliet: Med medborgaren i centrum Regeringens strategi för en digitalt samverkande statsförvaltning. Näringsdepartementet (2012)

32. Regeringskansliet: För ett hållbart digitaliserat sverige - en digitaliseringsstrategi (2017)

33. Regeringskansliet: SOU 2018:72 Slutrapport. Expertgruppen för digitala investeringar (2018)

34. Riksrevisionen: Vem styr den elektroniska förvaltningen? (2004)

35. Riksrevisionsverket: Persondatorer och skrivautomater - användning i statsförvaltningen (1984)

36. Rose, J., Flak, L.S.: Øystein Sæbø: Stakeholder theory for the e-government context: framing a value-oriented normative core. Gov. Inf. Q. 35(3), 362-374 (2018)

37. Rose, J., Persson, J.S., Heeager, L.T., Irani, Z.: Managing e-government: value positions and relationships. Inf. Syst. J. 25(5), 531-571 (2015)

38. Statskontoret: Efterstudier - att utvärdera effekterna av AU/ADB (1987)

39. Statskontoret: Staten i omvandling (1996)

40. Weber, M.: Economy and Society (reprint of the original from 1922). Bedminster Press, New York (1968) 